\title{
Combination of biodiesel-ethanol-diesel fuel blend and SCR catalyst assembly to reduce emissions from a heavy-duty diesel engine
}

\author{
SHI Xiaoyan ${ }^{1}$, YU Yunbo $^{1}$, HE Hong ${ }^{1, *}$, SHUAI Shijin ${ }^{2}$, DONG Hongyi ${ }^{2}$, LI Rulong ${ }^{2}$ \\ 1. State Key Laboratory of Environmental Chemistry and Ecotoxicology, Research Center for Eco-Environmental of Sciences, Chinese Academy of \\ Sciences, Beijing 100085, China.E-mial: Shi.xiaoy@gmail.com \\ 2. State Key Laboratory of Automotive Safety and Energy, Tsinghua University, Beijing, 100084, China
}

Received 23 April 2007; revised 10 August 2007; accepted 10 September 2007

\begin{abstract}
In this study, the efforts to reduce $\mathrm{NO}_{x}$ and particulate matter (PM) emissions from a diesel engine using both ethanol-selective catalytic reduction (SCR) of $\mathrm{NO}_{x}$ over an $\mathrm{Ag} / \mathrm{Al}_{2} \mathrm{O}_{3}$ catalyst and a biodiesel-ethanol-diesel fuel blend (BE-diesel) on an engine bench test are discussed. Compared with diesel fuel, use of BE-diesel increased PM emissions by $14 \%$ due to the increase in the soluble organic fraction (SOF) of PM, but it greatly reduced the Bosch smoke number by $60 \%-80 \%$ according to the results from 13-mode test of European Stationary Cycle (ESC) test. The SCR catalyst was effective in $\mathrm{NO}_{x}$ reduction by ethanol, and the $\mathrm{NO}_{x}$ conversion was approximately $73 \%$. Total hydrocarbons (THC) and CO emissions increased significantly during the SCR of $\mathrm{NO}_{x}$ process. Two diesel oxidation catalyst (DOC) assemblies were used after $\mathrm{Ag} / \mathrm{Al}_{2} \mathrm{O}_{3}$ converter to remove $\mathrm{CO}$ and $\mathrm{HC}$. Different oxidation catalyst showed opposite effect on PM emission. The PM composition analysis revealed that the net effect of oxidation catalyst on total PM was an integrative effect on SOF reduction and sulfate formation of PM. The engine bench test results indicated that the combination of BE-diesel and a SCR catalyst assembly could provide benefits for $\mathrm{NO}_{x}$ and $\mathrm{PM}$ emissions control even without using diesel particle filters (DPFs)
\end{abstract}

Key words: diesel engine; biomass fuel; selective catalytic reduction; $\mathrm{NO}_{x}$; particulate matter $(\mathrm{PM})$

\section{Introduction}

Emissions of nitrogen oxides $\left(\mathrm{NO}_{x}\right)$ and particulate matter (PM) are the main pollutants produced by diesel engines. Increasingly stringent emissions regulations have resulted in the growing demand for diesel engine emissions control technology. Meeting this demand will require changes in fuel composition, engine improvement, and improvements of after treatment technology. For most in use diesel engines, the improvements of fuel and aftertreatment technology are the points which can achieve benefits recently.

Selective catalytic reduction (SCR) is one of the most promising after treatment technologies for the removal of $\mathrm{NO}_{x}$ from diesel exhaust. Among the many possible catalysts, $\mathrm{Ag} / \mathrm{Al}_{2} \mathrm{O}_{3}$ is one of the most effective ( $\mathrm{He}$ and $\mathrm{Yu}$, 2005). SCR of $\mathrm{NO}_{x}$ by ethanol over $\mathrm{Ag} / \mathrm{Al}_{2} \mathrm{O}_{3}$ has shown high effectiveness and low sulfur sensitivity in laboratory studies (Sumiya et al., 1998; Wu et al., 2006). Several researchers have investigated this process on an actual diesel engine bench and have shown that ethanol-SCR of $\mathrm{NO}_{x}$ over $\mathrm{Ag} / \mathrm{Al}_{2} \mathrm{O}_{3}$ is a promising de- $\mathrm{NO}_{x}$ technology for diesel engine emission control (Nagashima et al., 2002; Kass et al., 2003; Shuai et al., 2005; Zhang et al., 2006).

\footnotetext{
* Corresponding author. E-mail: honghe@rcees.ac.cn.
}

For $\mathrm{NO}_{x}$ reduction by ethanol over $\mathrm{Ag} / \mathrm{Al}_{2} \mathrm{O}_{3}$, the possibility that hydrocarbon (HC) emission could increase because of unused ethanol and the generation of oxygenated HCs, especially acetaldehyde, must be considered (Zhang et al., 2005). In addition, some researchers reported that a considerable amount of $\mathrm{CO}$ could be produced during $\mathrm{NO}_{x}$ reduction by octane, propene, or ethanol over $\mathrm{Ag} / \mathrm{Al}_{2} \mathrm{O}_{3}$ (Zhang et al., 2005; Shi et al., 2005a; Eränen et al., 2003). Thus, to reduce $\mathrm{HC}$ and $\mathrm{CO}$ emissions produced during the ethanol-SCR of $\mathrm{NO}_{x}$ over $\mathrm{Ag} / \mathrm{Al}_{2} \mathrm{O}_{3}$, an oxidation catalyst should be used after the $\mathrm{Ag} / \mathrm{Al}_{2} \mathrm{O}_{3}$. For example, Eränen et al. (2003) placed a Pt-oxidation catalyst after the $\mathrm{Ag} / \mathrm{Al}_{2} \mathrm{O}_{3}$ to remove the $\mathrm{CO}$ and unburned $\mathrm{HCs}$ during the $\mathrm{HC}$ (octane)-SCR of $\mathrm{NO}_{x}$ process. However, a drastic decrease in NO conversion was observed when the distance between the two catalysts was short (Eränen et al., 2003). This result indicates that a high-activity oxidation catalyst, especially a noble metalsupported catalyst, might be unsuitable for placement directly after $\mathrm{Ag} / \mathrm{Al}_{2} \mathrm{O}_{3}$. On the other hand, Miyadera (1998) reported that $\mathrm{CuSO}_{4} / \mathrm{TiO}_{2}$ was effective for removing nitrogen-containing byproducts, which are produced by the SCR of $\mathrm{NO}_{x}$ by ethanol over $\mathrm{Ag} / \mathrm{Al}_{2} \mathrm{O}_{3}$.

As public concern about environmental pollution and energy security increases, research into alternative diesel 
fuels is attracting more and more attention. Biodiesel and ethanol are the two most widely used biofuels; both can be produced from biomass and can provide environmental and energy benefits. They also are renewable energy sources, and many studies have shown that biodiesel and ethanol can help reduce PM emissions (Graboski and McCormick, 1998; Durbin et al., 2000, 2002; Wang et al., 2000; Hansen et al., 2005; Ahmed, 2001). In previous studies, a biodiesel-ethanol-diesel fuel blend (BE-diesel) on two diesel engines was tested and it was found that it can be used directly in diesel engines and can achieve a maximum $40 \%$ reduction in PM emissions (Shi et al., 2005b, 2006). Thus, BE-diesel is considered to be a potential alternative to diesel fuel that can be used in commercial diesel engines.

This study was designed primarily to reduce $\mathrm{NO}_{x}$ and PM emissions from a diesel engine through the simultaneous use of ethanol-SCR of $\mathrm{NO}_{x}$ over an $\mathrm{Ag} / \mathrm{Al}_{2} \mathrm{O}_{3}$ catalyst and BE-diesel. The performance of $\mathrm{Ag} / \mathrm{Al}_{2} \mathrm{O}_{3}$ for the SCR of $\mathrm{NO}_{x}$ was first considered under the real exhaust condition produced by the BE-diesel fuel blend. Diesel particle filters (DPFs) have been proven to be very effective in PM reduction (Van Setten et al., 2001). However, in the current study, BE-diesel was expected to reduce PM and no DPF was applied. In addition, the impact of SCR$\mathrm{NO}_{x}$ after treatment catalyst systems on PM emissions was also considered. Overall, the experiments were performed under the following conditions: diesel fuel/no catalyst; BE-diesel/no catalyst; BE-diesel/SCR catalyst + different oxidation catalyst assemblies.

\section{Experimental}

\subsection{Diesel engine and test fuels}

A 5.12-L, four-cylinder, direct injection/turbocharged intercooling heavy-duty diesel engine was used in this study. The main specifications of the diesel engine are shown in Table 1.

The two fuels used in this study were a Chinese market 0 \# diesel fuel (hereafter named D) and a blend of the same diesel fuel, biodiesel (20\% on a volume basis), and ethanol (5\% on a volume basis), referred to as BEdiesel. The ethanol, biodiesel and diesel fuel are simply blended. Biodiesel can act as an emulsifier and the ethanol is emulsified into the fuel blend. The BE-diesel fuel can be stable at least for 3 months (Shi et al., 2005b, 2006). The sulfur content of the diesel fuel was $0.031 \%$ on a weight basis (sulfur content was analyzed according to GB2522000, China). The biodiesel was methyl soyate, which is

Table 1 Engine specifications

\begin{tabular}{ll}
\hline Cylinder number & 4 \\
\hline Bore $(\mathrm{mm}) \times$ stroke $(\mathrm{mm})$ & $102 \times 120$ \\
Displacement $(\mathrm{L})$ & 5.12 \\
Compression ratio & $17.5: 1$ \\
Fuel pump & $\mathrm{BH} 4 \mathrm{P} 120 \mathrm{R} 1402$ \\
Rated power $(\mathrm{kW}) /$ speed $(\mathrm{r} / \mathrm{min})$ & $132 / 2300$ \\
Maximum torque $(\mathrm{N} \cdot \mathrm{m}) / \mathrm{speed}(\mathrm{r} / \mathrm{min})$ & $660 / 1300-1500$ \\
\hline
\end{tabular}

made from soybean oil and methanol. The sulfate content of biodiesel was negligible.

\subsection{Catalysts and test cycle}

The after treatment catalysts were designed based on the previous laboratory results (Zhang et al., 2005). The $\mathrm{Ag} / \mathrm{Al}_{2} \mathrm{O}_{3}$ wash-coated honeycomb catalyst was used for $\mathrm{NO}_{x}$ reduction. Ethanol was added to the system by a reductant-adding device as a reductant agent for the SCR of $\mathrm{NO}_{x}$, as described by Shuai et al. (2005). Ethanol dosing was based on the molar ratio of ethanol : $\mathrm{NO}_{x}=1: 1$. Two different oxidation catalyst assemblies were placed after the $\mathrm{Ag} / \mathrm{Al}_{2} \mathrm{O}_{3}$ catalyst substrate to investigate their effectiveness in removing $\mathrm{HCs}$ and $\mathrm{CO}$ : (1) $3.08 \mathrm{~L} \mathrm{Cu} / \mathrm{TiO}_{2}$ catalyst substrate and (2) $1.54 \mathrm{~L} \mathrm{Cu} / \mathrm{TiO}_{2}+1.54 \mathrm{~L} \mathrm{Pt}-$ supported catalyst substrate. The $\mathrm{Ag} / \mathrm{Al}_{2} \mathrm{O}_{3}+\mathrm{Cu} / \mathrm{TiO}_{2}$ catalyst assembly is denoted as SCR + DOC I and the $\mathrm{Ag} / \mathrm{Al}_{2} \mathrm{O}_{3}+\mathrm{Cu} / \mathrm{TiO}_{2}+$ Pt-supported catalyst assembly is denoted as SCR + DOC II. The fuel and after treatment combinations are summarized in Table 2.

Table 2 Fuel and after treatment combinations

\begin{tabular}{|c|c|}
\hline Fuel and after treatment combinations & Denoted \\
\hline Diesel fuel & $\mathrm{D}$ \\
\hline BE-diesel & $\mathrm{BE}$ \\
\hline BE-diesel $+\mathrm{Ag} / \mathrm{Al}_{2} \mathrm{O}_{3}$ catalyst & $\mathrm{BE} / \mathrm{SCR}$ \\
\hline $\mathrm{BE}$-diesel $+\mathrm{Ag} / \mathrm{Al}_{2} \mathrm{O}_{3}+\mathrm{Cu} / \mathrm{TiO}_{2}$ catalysts & $\mathrm{BE} / \mathrm{SCR}+\mathrm{DOC} \mathrm{I}$ \\
\hline $\begin{array}{l}\text { BE-diesel }+\mathrm{Ag} / \mathrm{Al}_{2} \mathrm{O}_{3}+\mathrm{Cu} / \mathrm{TiO}_{2} \\
\quad+\text { Pt-supported catalysts }\end{array}$ & $\mathrm{BE} / \mathrm{SCR}+\mathrm{DOC}$ II \\
\hline
\end{tabular}

All of the catalyzed honeycomb ceramic substrates used in the current study were the same type: 200 cells/in ${ }^{2}$ (31 cells $/ \mathrm{cm}^{2}$ ), $140 \mathrm{~mm}$ diameter and $100 \mathrm{~mm}$ long, and round cordierite with $0.017 \mathrm{~cm}$ wall thickness. The exhaust after treatment system comprised of $9.24 \mathrm{~L} \mathrm{SCR}-\mathrm{NO}_{x}$ honeycomb catalyst substrate and $3.08 \mathrm{~L}$ oxidation honeycomb catalyst substrate, in series. The washcoated loadings of $\mathrm{Ag} / \mathrm{Al}_{2} \mathrm{O}_{3}$ and $\mathrm{Cu} / \mathrm{TiO}_{2}$ on honeycomb substrates were around 130 and $110 \mathrm{~g} / \mathrm{L}$, respectively.

The steady state 13-mode test cycle of the European stationary cycle (ESC) was used in the current study. Because the $\mathrm{Ag} / \mathrm{Al}_{2} \mathrm{O}_{3}$ catalyst is not active for the SCR of $\mathrm{NO}_{x}$ by ethanol when the gas temperature is below $300^{\circ} \mathrm{C}$, ethanol was not added into the system at low exhaust temperature test modes. Table 3 shows the exhaust gas conditions and the ethanol dosing strategy used in this study.

\subsection{Measurement experiments}

An exhaust gas analyzer (AVL CEB-11, Austria) was used to measure emissions of $\mathrm{NO}_{x}$, THC, and $\mathrm{CO}$ on line in raw exhaust. THC was analyzed with a flame ionization detector (FID), CO was analyzed with a non-dispersive infrared analyzer (NDIR), and $\mathrm{NO}_{x}$ was analyzed with a chemiluminescent. The relative standard deviations of the analyzer were $<1 \%$ for $\mathrm{NO}_{x},<3 \%$ for THC, and $<5 \%$ for CO. Total PM was measured by an AVL PM sampler with exhaust dilution and a sampling system (SPC472, Austria). The dilution ratio was 5\%. PM was collected on a 
Table 3 Exhaust gas conditions and ethanol dosing strategy

\begin{tabular}{lllll}
\hline Mode & $\begin{array}{l}\text { Speed } \\
(\mathrm{r} / \mathrm{min})\end{array}$ & $\begin{array}{l}\text { Torque } \\
(\mathrm{N} \cdot \mathrm{m})\end{array}$ & $\begin{array}{l}\text { Exhaust } \\
\text { temp. }\left({ }^{\circ} \mathrm{C}\right)\end{array}$ & $\begin{array}{l}\text { Ethanol } \\
\text { inject }\end{array}$ \\
\hline 1 & 744 & 0 & 89 & - \\
2 & 1450 & 645 & 470 & + \\
3 & 1800 & 297 & 370 & + \\
4 & 1800 & 448 & 391 & + \\
5 & 1450 & 316 & 334 & + \\
6 & 1450 & 475 & 394 & + \\
7 & 1450 & 158 & 242 & - \\
8 & 1800 & 596 & 463 & + \\
9 & 1800 & 149 & 250 & + \\
10 & 2150 & 541 & 491 & + \\
11 & 2150 & 135 & 253 & + \\
12 & 2150 & 405 & 390 & + \\
13 & 2150 & 207 & 319 & \\
\hline “_" no ethanol injection; “+” ethanol injection. &
\end{tabular}

"_" no ethanol injection; "+" ethanol injection.

PTFE-coated glass filter (AVL, Austria) and the filtered gas temperature was below $52^{\circ} \mathrm{C}$. The filter was conditioned at $25^{\circ} \mathrm{C}$ and $50 \%$ humidity, and it was weighed before and after the sampling procedure.

$\mathrm{SO}_{2}$ emissions were analyzed with a $\mathrm{SO}_{2}$ analyzer (ECOTECH ML $9850 \mathrm{H}$, Austria) with a detection limit of 1 ppmv. Each test mode was keeping 15 min to get steady state results of the $\mathrm{SO}_{2}$ concentration in the exhaust.

Diesel PM is a complex mixture of elemental carbon, a variety of $\mathrm{HCs}$, sulfur compounds, and other species (Burtscher, 2005). In this study, PM was fractionated in terms of the soluble organic fraction (SOF), dry soot (DS), and sulfate/water. The PM collected on the PTFE-coated filter was first extracted with dichloromethane and the weight loss by dichloromethane extraction was assigned to SOF (Stratakis and Stamatelos, 2003; Boehman et al., 2005; Stein, 1996; Hosoya and Shimoda, 1996). The filter was then extracted with deionized water. This fraction included sulfate, nitrate, and other water-soluble salts, but most of this fraction is composed of sulfate and sulfateassociated water (Wang et al., 2000; Stein, 1996; Hosoya and Shimoda, 1996; Gekas et al., 2002). The weight loss of the water-extracted portion is referred to as "sulfate/water". The remaining weight of the PM is considered to be DS. The sum of SOF, DS, and sulfate/water is equal to total PM. Although this mass filter analysis was simple, it provided a good indication of the percentage of volatile compounds, carbon, and water-soluble salts (mostly soluble sulfate) in PM.

\section{Results}

\subsection{Regulated emissions: Effects of fuel and assembly catalysts}

Table 4 summarizes the results of the ESC 13-mode cycle tests of $\mathrm{NO}_{x}, \mathrm{THC}$, and $\mathrm{CO}$ emissions from the diesel engine operating with different fuels and different catalyst assemblies (the original engine emissions with diesel fuel and BE-diesel in absence of any catalyst are denoted as $\mathrm{D}$ and $\mathrm{BE}$ respectively). The data obtained from the raw exhaust passing trough the SCR, SCR + DOC I, and SCR + DOC II assemblies when the engine was fueled by
Table 4 Emissions of $\mathrm{NO}_{x}, \mathrm{THC}$, and CO

\begin{tabular}{llllll}
\hline $\begin{array}{l}\text { Emission } \\
(\mathrm{g} / \mathrm{kWh})\end{array}$ & $\mathrm{D}$ & $\mathrm{BE}$ & $\mathrm{BE} / \mathrm{SCR}$ & $\begin{array}{l}\mathrm{BE} / \mathrm{SCR} \\
+ \text { DOC I }\end{array}$ & $\begin{array}{l}\text { BE/SCR } \\
+ \text { DOC II }\end{array}$ \\
\hline $\mathrm{NO}_{x}$ & 11.36 & 11.99 & 3.26 & 3.42 & 4.63 \\
$\mathrm{THC}$ & 0.39 & 0.25 & 1.67 & 0.58 & 0.34 \\
$\mathrm{CO}$ & 0.32 & 0.31 & 4.14 & 2.61 & 0.34 \\
\hline
\end{tabular}

BE-diesel are coded as BE/SCR, BE/SCR + DOC I, and $\mathrm{BE} / \mathrm{SCR}+\mathrm{DOC} \mathrm{II}$, respectively. All tests were repeated, and the data in Table 4 represent the average of the two tests.

Table 4 shows that the use of BE-diesel rather than diesel fuel resulted in a small increase in $\mathrm{NO}_{x}$ emissions (approximately $5.5 \%$ ), which agrees with the previous results (Shi et al., 2005b, 2006). The increase in $\mathrm{NO}_{x}$ emissions might be attributed to the presence of methyl soyate in BE-diesel. The original engine's emitted THC decreased with the use of BE-diesel, whereas the $\mathrm{CO}$ emissions were almost neutral in the current study compared with the use of diesel fuel.

The $\mathrm{Ag} / \mathrm{Al}_{2} \mathrm{O}_{3}$ was an effective catalyst for $\mathrm{NO}_{x}$ reduction by ethanol: The $\mathrm{NO}_{x}$ conversion was about $73 \%$ in comparison with $\mathrm{BE}$ and BE/SCR. It should be noted, however, that THC and $\mathrm{CO}$ emissions increased greatly after the SCR of $\mathrm{NO}_{x}$ by ethanol over the $\mathrm{Ag} / \mathrm{Al}_{2} \mathrm{O}_{3}$ catalyst. Compared with the original emissions produced by the use of BE-diesel (BE in Table 4), CO emission increased about 13 times and THC emission increased about 7 times after going through the SCR catalyst assembly (BE/SCR in Table 4). The increase in THC emissions was mainly caused by the addition of the ethanol that remained after the SCR process.

The oxidation catalysts that were placed after the SCR catalyst were expected to eliminate the $\mathrm{CO}$ and THC emissions produced during the SCR process. Reduction rates of $71 \%$ for $\mathrm{NO}_{x}$ compared with $\mathrm{BE}, 50 \%$ for $\mathrm{CO}$, and $60 \%$ for THC compared with BE/SCR were achieved with the SCR + DOC I catalyst assembly. However, THC and $\mathrm{CO}$ emissions were still greater than those of the original engine-emitted exhaust (BE in Table 4). The SCR + DOC II catalyst assembly achieved $61 \%$ reduction of $\mathrm{NO}_{x}$ compared with the $\mathrm{NO}_{x}$ generated using BE-diesel without a catalyst and $70 \%$ of $\mathrm{CO}$, and $80 \%$ of THC emissions compared with the BE/SCR case .

\subsection{PM mass emission and the composition of PM: Effects of fuel and catalysts}

Figure 1 shows the ESC 13-mode test results for total PM mass emissions and the simple composition of PM under different operating conditions. Using BE-diesel increased PM emissions by $16 \%$ compared with using diesel fuel. This result is in contrast to the previous results, in which using BE-diesel reduced PM emissions (Shi et al., 2005b, 2006). However, diesel engines used in the two studies were different, which may account for the different results. In fact, most previous studies showed that oxygenated fuels produced lower PM emissions than diesel fuel. However, Durbin et al. (2000) and Wang et al. (2000) suggested that the effect of fuel on PM emissions 


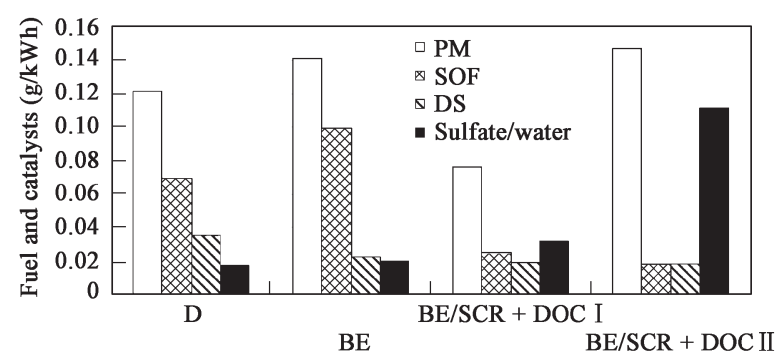

Fig. 1 Effect of fuel and catalysts on PM emissions and the composition of the PM.

varies significantly from vehicle to vehicle. Some studies have shown that biodiesel and diesel fuel blends increased PM emissions (Wang et al., 2000; Durbin et al., 2001). In this study, analysis of PM collected on filters revealed that use of BE-diesel decreased the DS portion, significantly increased the SOF (42\%), and slightly increased the sulfate/water portion of PM, resulting in a net increase in total PM emission. The increase in SOF with use of BE-diesel might be caused by unburned ester condensed on the particulates because of the low volatility of methyl soyate. Although the use of BE-diesel did not result in PM reduction in the present study, it significantly decreased the smoke emissions from the diesel engine. Except in the idle modes, in which the Bosch smoke number was measured as zero for both diesel fuel and BE-diesel, the Bosch smoke number was decreased $60 \%-80 \%$ (depending on test mode) when BE-diesel was used.

After treatment catalyst assemblies also affected the total PM emissions. Because SOF consists mainly of volatile organic materials, which are easily oxidized (Stein, 1996; Hosoya and Shimoda, 1996), it has been suggested that using an oxidation catalyst might reduce PM emissions. In fact, when the diesel engine was fueled by BE-diesel, the SCR + DOC I catalyst assembly decreased PM emissions by $46 \%$; in contrast, the SCR + DOC II catalyst assembly increased PM emissions by about $4 \%$, compared to the value without the catalyst assembly. Composition analysis results revealed that the net effect of catalyst assemblies on total PM emission was a combination of SOF, DS, and sulfate/water reactivities. Fig. 1 shows that the SCR + DOC I catalyst assembly significantly decreased the SOF by about $74 \%$ but increased the sulfate/water portion, compared with BE-diesel original PM emission. SOF reduction was greater over the SCR + DOC II catalyst assembly than over the SCR + DOC I catalyst assembly, but the sulfate/water portion was increased by approximately 5.5 times compared with BE-diesel original PM emission in the absence of the catalyst. Both catalyst assemblies showed slight effect on the DS portion of PM.

\subsection{Sulfur dioxide emissions: Effects of fuel and catalyst assembly}

Figure 2 shows the $\mathrm{SO}_{2}$ emissions from the 13-mode test cycle of the ESC. The sulfur content of BE-diesel is about $25 \%$ lower than that of diesel fuel because of the $25 \%$ volume of biodiesel and ethanol in the fuel blend. In theory, BE-diesel was expected to emit less $\mathrm{SO}_{2}$ than

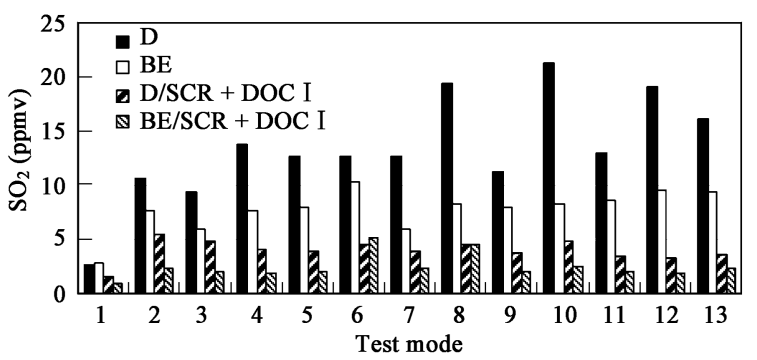

Fig. $2 \mathrm{SO}_{2}$ emissions in the exhaust of each mode of the ESC 13-mode test cycle.

diesel fuel and the reduction ratio to be proportional to the amount of sulfur-free fuel addition. Fig. 2 shows that a $38 \%$ reduction in $\mathrm{SO}_{2}$ emission was achieved using BE-diesel. It should be noted that the reduction in $\mathrm{SO}_{2}$ was higher than expected.

An oxidation catalyst can improve the $\mathrm{SO}_{2}$ to $\mathrm{SO}_{3}$ conversion efficiency and therefore decrease $\mathrm{SO}_{2}$ emissions. Fig. 2 shows that the SCR + DOC I catalyst had almost the same $\mathrm{SO}_{2}$ conversion efficiency for both diesel and BEdiesel: The $\mathrm{SO}_{2}$ concentration of the exhaust after SCR + DOC I decreased by $66 \%$ with the use of diesel fuel and $68 \%$ with the use of BE-diesel. The SCR + DOC II catalyst assembly showed a very high $\mathrm{SO}_{2}$ conversion efficiency. In this case, except in the idle mode, the $\mathrm{SO}_{2}$ concentration of the exhaust was too low to be detected by the $\mathrm{SO}_{2}$ analyzer used in this study. The high $\mathrm{SO}_{2}$ conversion efficiency of this catalyst assembly is attributed to the Pt-supported catalyst, which has extremely high activity for $\mathrm{SO}_{2}$ oxidation under the exhaust temperature range (200-500 $\left.{ }^{\circ} \mathrm{C}\right)$ (Maricq et al., 2002).

\section{Discussion}

The primary objective of this study was to reduce the $\mathrm{PM}$ and $\mathrm{NO}_{x}$ emissions of a diesel engine using oxygenated diesel fuel and an SCR + DOC catalyst assembly. The results of this study confirm that the ethanol-SCR of $\mathrm{NO}_{x}$ over $\mathrm{Ag} / \mathrm{Al}_{2} \mathrm{O}_{3}$ is an efficient method for $\mathrm{NO}_{x}$ removal from diesel engine fueled with both diesel fuel and BEdiesel. However, the ethanol-SCR in the current study corresponded to around $6 \%$ fuel penalty. A major problem associated with this SCR technology is the choice of a suitable oxidation catalyst. In the present study, the SCR + DOC I catalyst assembly was able to simultaneously reduce both $\mathrm{NO}_{x}$ and $\mathrm{PM}$ emissions. However, THC and $\mathrm{CO}$ emissions were still higher than those of original diesel engine emissions. The SCR + DOC II catalyst assembly showed much higher activity for $\mathrm{CO}$ and $\mathrm{HC}$ conversions and a lower $\mathrm{NO}_{x}$ conversion compared with SCR + DOC I. However, this catalyst assembly led to considerable sulfate formation and thus resulted in a net increase in total PM emissions.

This study revealed that fuel sulfur content was a crucial factor affecting PM emissions when after treatment catalysts were used with a diesel engine. Generally speaking, the catalyst could affect PM emissions in three ways: diesel soot oxidation, SOF removal, and sulfate formation 
(Maricq et al., 2002). Both catalysts assemblies applied in the present study affected the DS fraction slightly but greatly decreased the SOF in PM. Therefore, sulfate formation could be the key factor affecting the net total $\mathrm{PM}$ emission. The oxidation of $\mathrm{SO}_{2}$ to $\mathrm{SO}_{3}$ and the formation of sulfate depend on catalyst efficiency. Pt-supported diesel oxidation catalysts increased PM emissions due to considerable sulfate formation (Stein, 1996; Hosoya and Shimoda, 1996; Maricq et al., 2002). Compared with noble metal-supported catalysts, which are high activity oxidation catalysts, the base metal oxide catalyst $\mathrm{Cu} / \mathrm{TiO}_{2}$ showed lower oxidation activity. For the SCR + DOC I catalyst assembly, a significant reduction in SOF and a slight increase in sulfate resulted in a net reduction in PM emissions. For the SCR + DOC II catalyst assembly, a significant reduction in SOF but a considerable sulfate formation was attributed to the increase in the net total PM emissions.

In the present study, the sulfate/water portion of PM was found to be higher with the use of BE-diesel than with diesel fuel. Durbin et al. (2000) investigated the sulfate $\left(\mathrm{SO}_{4}{ }^{2-}\right)$ content of PM from four light-duty diesel trucks with four fuels using ion chromatography. In their study, $80 \%$ California diesel/20\% biodiesel ( $80 / 20$ blend) and neat biodiesel decreased the sulfur content of fuel by $15 \%$ and $88 \%$, respectively, compared with California diesel. However, the $\mathrm{SO}_{4}{ }^{2-}$ content of $\mathrm{PM}$ from tow trucks using the $80 / 20$ blend and from one truck using neat biodiesel was higher than that when the vehicles used diesel fuel (Durbin et al., 2000). Taking the fuel sulfur content differences into account, greater sulfur to sulfate conversion occurred with the $80 / 20$ blend and neat biodiesel compared with diesel fuel. In the present study, BE-diesel reduced more $\mathrm{SO}_{2}$ and the sulfate/water portion of PM was higher compared with diesel fuel, as was expected. Other researchers reported similar results for experiments testing ethanol-diesel fuel on a diesel engine (Özer et al., 2004). Overall, these results indicate that oxygenated fuels might cause more sulfate formation compared with diesel fuel.

BE-diesel can be used directly on diesel engines. However, a consequence of the lower energy content of BE-diesel is its higher break-specific fuel consumption (BSFC). In the current study, BSFC was $225.4 \mathrm{~g} /(\mathrm{kWh})$ for BE-diesel and $213.5 \mathrm{~g} /(\mathrm{kWh})$ for diesel fuel, when operating according to the steps in the 13-mode ESC cycle. However, $25 \%$ of the BE-diesel consisted of biodiesel (methyl soyate) and ethanol, which can be produced from biomass. Although using BE-diesel might increase total PM emissions because of the increase in SOF, it can decrease the DS portion of PM. As the results of this study have shown, SOF can be easily reduced with a catalyst assembly. If a low-sulfur diesel fuel is used, PM emissions can be greatly reduced by SOF removal without sulfate formation. It was expected that once the SCR + DOC II catalyst assembly is used in conjunction with BE-diesel which is based on a low-sulfur diesel fuel, $\mathrm{NO}_{x}$ and PM reduction can be achieved simultaneously.

\section{Conclusions}

$\mathrm{Ag} / \mathrm{Al}_{2} \mathrm{O}_{3}$-ethanol system was extremely effective for the $\mathrm{NO}_{x}$ reduction when the diesel engine was fueled by both diesel fuel and biodiesel-ethanol-diesel fuel blends. A considerable amount of $\mathrm{CO}$ and THC produced from the SCR process due to ethanol adding to the system as reductant. Two oxidation catalyst combinations were applied for the elimination of the $\mathrm{CO}$ and THC emission. Those two oxidation catalysts showed different effect on PM emission. By analysis of PM composition, it was found that the influence of oxidation catalyst on PM emission was a net effect of SOF reduction and sulfate formation. As a result, the combination of BE-diesel and a SCR catalyst assembly can effectively reduce both $\mathrm{NO}_{x}$ and $\mathrm{PM}$ emissions without using diesel particle filters.

\section{Acknowledgements}

This work was supported by the National Natural Science Foundation of China (No. 20425722, 20621140004) and the Ministry of Science and Technology of China (No. 2006AA060304).

\section{References}

Ahmed I, 2001. Oxygenated diesel: emissions and performance characteristics of ethanol-diesel blends in CI engines. SAE paper, No. 2001-01-2475.

Boehman A L, Song J, Alam M, 2005. Impacte of biodiesel blends on diesel soot and the regeneration of particulate filters. Energy and Fuel, 19: 1857-1864.

Burtscher H, 2005. Physical characterization of particulate emissions from diesel engines: a review. J Aerosol Sci, 36: 896-932.

Durbin T D, Collins J R, Norbeck J M, Smith M R, 2000. Effects of biodiesel, biodiesel blends, and a synthetic diesel on emissions from light heavy-duty diesel vehicles. Environ Sci Technol, 34: 349-355.

Durbin T D, Cocker K, Collins J F, Norbeck J M, 2001. Final report: Evaluation of the effects of biodiesel and biodiesel blends on exhaust emission rates and reactivity2. SCAQMD contact 99120.

Durbin T D, Norbeck J M, 2002. Effects of biodiesel blends and Acro EC-diesel on emissions from light heavy-duty diesel vehicles. Environ Sci Technol, 36: 1686-1691.

Eränen K, Lindfors L E, Klingstedt F, Murzin D Y, 2003. Continuous reduction of $\mathrm{NO}$ with octane over a silver/alumina catalyst in oxygen-rich exhaust gases: combined heterogeneous and surface-mediated homogeneous reactions. $J$ Catal, 219: 25-40.

Gekas I, Gabrielsson P, Johansen K, Bjørn I, Kjær J H, Reczek W, Cartellieri W, 2002. Performance of a urea SCR system combined with a PM and fuel optimized heavy-duty diesel engine able to achieve the Euro $\mathrm{V}$ emission limits. SAE paper, No. 2002-01-2885.

Graboski M S, McCormick R L, 1998. Combustion of fat and vegetable oil derived fuels in diesel engines. Prog Energy Combus Sci, 24: 125-164.

Hansen A C, Zhang Q, Lyne P W L, 2005. Ethanol-diesel fuel blends-a review. Bioresource Technol, 96: 277-285.

$\mathrm{He} \mathrm{H}, \mathrm{Yu}$ Y B, 2005. Selective catalytic reduction of $\mathrm{NO}_{x}$ 
over $\mathrm{Ag} / \mathrm{Al}_{2} \mathrm{O}_{3}$ catalyst: from reaction mechanism to diesel engine test. Catal Today, 100: 37-47.

Hosoya M, Shimoda M, 1996. The application of diesel oxidation catalysts to heavy duty diesel engines in Japan. Appl Catal $B, 10$ : 83-97.

Kass M D, Thomas J F, Lewis S, Storey J M, Graves R L, Panov A G, 2003. Selective catalytic reduction of $\mathrm{NO}_{x}$ emissions from a 5.9 liter diesel engine using ethanol as a reductant. SAE paper, No. 2003-01-3244.

Maricq M M, Chase R E, Xu N, Laing P M, 2002. The effect of the catalytic converter and fuel sulfur level on motor vehicle particulate matter emissions: light duty diesel vehicles. Environ Sci Technol, 36: 283-289.

Miyadera T, 1998. Selective reduction of $\mathrm{NO}_{x}$ by ethanol on catalysts composed of $\mathrm{Ag} / \mathrm{Al}_{2} \mathrm{O}_{3}$ and $\mathrm{Cu} / \mathrm{TiO}_{2}$ without formation of harmful by-products. Appl Catal B, 16: 155164.

Nagashima K, Nagata M, Katou K, Sod K, Sugigama M, 2002. Development of deNO $\mathrm{N}_{x}$ catalyst based on $\mathrm{Ag} / \mathrm{Al}_{2} \mathrm{O}_{3}$ catalyst for diesel applications. SAE paper, No. 2002-01-1724.

Özer C, smet Ç, Nazım U, 2004. Effects of ethanol addition on performance and emissions of a turbo charged indirect injection diesel engine running at different injection pressures. Energy Convers and Managet, 45: 2429-2440.

Shi X Y, Zhang C B, He H, 2005a. Selective catalytic reduction of $\mathrm{NO}_{x}$ by $\mathrm{C}_{3} \mathrm{H}_{6}$ over combined catalyst $\mathrm{Ag} / \mathrm{Al}_{2} \mathrm{O}_{3}-\mathrm{Cu} / \mathrm{Al}_{2} \mathrm{O}_{3}$ in the presence of excess oxygen. J Chin Catal, 26: 69-73.

Shi X, Yu Y, He H, Shuai S, Wang J, Li R, 2005b. Emission characteristics using methyl soyate-ethanol-diesel fuel blends on a diesel engine. Fuel, 84: 1543-1549.

Shi X Y, Pang X B, Mu Y J, He H, Shuai S J, Wang J X, Chen H, Li R L, 2006. Emission reduction potential from using ethanol-biodiesel-diesel fuel blend on a heavy-duty diesel engine. Atmospheric Environ, 40: 2567-2574.

Shuai S J, Wang J X, Li R L, Sun J J, Xing L C, He H, Shi X $\mathrm{Y}, 2005$. Performance evaluation and application of diesel $\mathrm{NO}_{x}$-SCR catalyst by ethanol reductant. SAE paper, No. 2005-01-1089.

Stein H J, 1996. Diesel oxidation catalysts for commercial vehicle engines: strategies on their application for controlling particulate emissions. Appl Catal B, 10: 69-82.

Stratakis G A, Stamatelos A M, 2003. Thermogravimetric analysis of soot emitted by a modern diesel engine run on catalyst-doped fuel. Combus Flame, 132: 157-169.

Sumiya S, Saito M, He H, Feng Q C, Takezawa N, Yoshida K, 1998. Reduction of lean $\mathrm{NO}_{x}$ by ethanol over $\mathrm{Ag} / \mathrm{Al}_{2} \mathrm{O}_{3}$ catalysts in the presence of $\mathrm{H}_{2} \mathrm{O}$ and $\mathrm{SO}_{2}$. Catal Lett, 50: 87-91.

Van Setten B A A L, Makkee M, Moulijn J A, 2001. Science and technology of catalytic diesel particulate filters. Catal Reviews, 43: 489-564.

Wang W G, Lyons D W, Clark N N, Gautam M, 2000. Emissions from nine heavy trucks fueled by diesel and biodiesel blend without engine modification. Environ Sci Technol, 34: 933939.

Wu Q, Feng Q C, He H, 2006. Disparate effects of $\mathrm{SO}_{2}$ on the selective catalytic reduction of $\mathrm{NO}$ by $\mathrm{C}_{2} \mathrm{H}_{5} \mathrm{OH}$ and IPA over $\mathrm{Ag} / \mathrm{Al}_{2} \mathrm{O}_{3}$. Catal Commun, 7: 657-661.

Zhang C B, Shi X Y, He H, 2005. Selective catalytic reduction of $\mathrm{NO}_{x}$ by ethanol over combined catalyst $\mathrm{Ag} / \mathrm{Al}_{2} \mathrm{O}_{3}$ $\mathrm{Cu} / \mathrm{Al}_{2} \mathrm{O}_{3}$ in excess oxygen. J Chin Catal, 26: 645-649.

Zhang C B, He H, Shuai S J, Wang J X, 2006. Catalytic performance of $\mathrm{Ag} / \mathrm{Al}_{2} \mathrm{O}_{3}-\mathrm{C}_{2} \mathrm{H}_{5} \mathrm{OH}-\mathrm{Cu} / \mathrm{Al}_{2} \mathrm{O}_{3}$ system for the removal of $\mathrm{NO}_{x}$ from diesel engine exhaust. Environ Pollution, 147: 415-421. 